\title{
VALIDATION STUDY OF AN OVERALL RADIATION BALANCE ESTIMATION METHOD UNDER PONTA GROSSA (PR) BRAZIL WEATHER CONDITIONS
}

\author{
GUSTAVO C. BERUSKI ${ }^{1}$, ANDRÉ B. PEREIRA ${ }^{2}$
}

\begin{abstract}
Radiation balance is the fraction of incident solar radiation upon earth surface which is available to be used in several natural processes, such as biological metabolism, water loss by vegetated surfaces, variation of temperature in farming systems and organic decomposition. The present study aimed to assess and validate the performance of two estimation models for $R n$ in Ponta Grossa city, Paraná State, Brazil. To this end, during the period of 04/01/2008 to 04/30/2011, from radiometric data collected by an automatic weather station set at the Experimental Station, of the State University of Ponta Grossa. We performed a linear regression study by confrontation between measurements made through radiometric balance and $R n$ estimates obtained from Brunt classical method, and the proposed method. Both models showed excellent performance and were confirmed by the statistical parameters applied. However, the alternative method has the advantage of requiring only global solar radiation values, temperature, and relative humidity.
\end{abstract}

KEYWORDS: overall radiation balance, Bowen ratio, global solar radiation, modeling, solar radiometry.

\section{VALIDAÇÃO DE MÉTODO DE ESTIMATIVA DO BALANÇO GERAL DE RADIAÇÃO SOB AS CONDIÇÕES CLIMÁTICAS DE PONTA GROSSA - PR}

RESUMO: O saldo de radiação é a fração da radiação solar e terrestre incidentes na superfície que está disponível para ser utilizada em diversos processos naturais, tais como metabolismo biológico, perda de água por superfícies vegetadas, variações de temperatura em sistemas agrícolas e decomposição orgânica. O presente estudo teve como objetivo aferir e validar o desempenho de dois modelos de estimativa de $R n$ no município de Ponta Grossa - PR. Para tanto, durante o período compreendido entre $1^{0}$-04-2008 e 30-04-2011, a partir de dados radiométricos coletados por uma estação meteorológica automática instalada na Estação Experimental da Universidade Estadual de Ponta Grossa, efetuou-se estudo de regressão linear simples mediante o confronto entre medidas realizadas por saldo-radiômetro e estimativas de $R n$ obtidas pela metodologia clássica de Brunt e pelo método proposto. Ambos os modelos apresentaram excelente desempenho, sendo confirmado pelos parâmetros estatísticos empregados. Porém, a metodologia alternativa tem como vantagem necessitar apenas de valores de radiação solar global, temperatura e umidade relativa do ar.

PALAVRAS-CHAVE: balanço geral de radiação, razão de Bowen, radiação solar global, modelagem, radiometria solar.

\section{INTRODUCTION}

Solar radiation is the major energy source for planet, acting directly on physiological processes in higher plants, and indirectly affecting the thermal regime of several terrestrial systems. In addition, this variable of the physical environment is closely related to plant productivity, since it affects the amount of carbohydrates produced by photosynthesis, as well as other plant-related and environmental processes. Water transfer from surface to atmosphere, heating and cooling of air and soil, as well as evapotranspiration depend on this source of energy (HELDWEIN et al., 2012).

\footnotetext{
${ }^{1}$ Biólogo, Doutorando em Agronomia, Departamento de Engenharia de Biossistemas, Escola Superior de Agricultura "Luiz de Queiroz”, ESALQ/USP, Piracicaba - SP, Fone: (19) 3429-4217, beruskigc@usp.br

${ }^{2}$ Engo ${ }^{\circ}$ Agrônomo, Professor Associado, Departamento de Solos e Engenharia Agrícola, Universidade Estadual de Ponta Grossa, UEPG, Ponta Grossa - PR, Fone: (42) 3220-3777, abelmont@uepg.br 
However, not all incident solar radiation on the planet will be available for use in earth processes. The solar energy fraction that is readily available for physical, chemical and biological processes is called radiation balance. Some considerations about the importance of energy balance and net radiation in determining water vapor flow in atmosphere are made by VILLANUEVA (1987). Several studies on net radiation monitoring, as well as on its partition aspects into various agricultural systems were developed by national and international researchers.

The partitioning of net radiation into latent heat flux of a vegetated system, as well as into other components of energy balance is closely linked to changes in land use and system water availability. Apart from its intrinsic importance in energy balance studies, net radiation is a key input variable in climatological models to assess evapotranspiration, and its precise estimate is essential for water resource management on regional scale (VILLA NOVA \& PEREIRA, 2006, VILLA NOVA et al., 2006; RYU et al., 2008; PEREIRA et al., 2009; PEREIRA et al., 2011), for frost prediction studies, and air pollution monitoring (FRITSCHEN \& FRITSCHEN, 2007).

Currently, automatic weather stations began to be widely disseminated throughout the national territory. Although they have sensors for the direct measurement of global solar radiation, they not always have sensors for measurements of important physical constants or even sensors for routine measurements of net radiation (LIMA et al., 2012). This causes unavailability of local weather information for agroecological studies, radiometry, and agricultural forecast.

For flat surface conditions, net radiation can be estimated through the combination of Angstrom-Prescott equations for short wave balance and Brunt equations for long wave; which is recommended by FAO (ALLEN et al., 1998; PEREIRA \& VILLA NOVA, 2002). To obtain such estimate, data on insolation ratio, partial pressure of water vapor and air temperature are required (SENTELHAS \& NASCIMENTO, 2003).

One possibility to calculate net radiation partition in latent and sensible heat fluxes, which are used in organic synthesis, is to determine the relation between sensible and latent heat flux by micrometeorological measurements. Bowen ratio is determined with additional measure of heat flux in soil and disregarding heat flux stored in vegetation. There is extensive literature quantifying radiation fluxes through Bowen ratio method - energy balance in different regions of the country and world. Its application ranges from determining the energy balance in crops or areas of interest, to determinate water loss and crop coefficients, to study water relations in plants and dams (PEREIRA, 2006). According to TODD et al. (2000), the Bowen ratio method is a micrometeorological method often used to estimate the latent heat flux due to its accuracy, low cost, simple operation and application at different ecosystems.

The present study aimed to assess and validate a physical-mathematical model to estimate net radiation on a vegetated surface with grass due to global solar radiation, relative humidity, and air temperature daily average under weather conditions of Ponta Grossa city, PR, Brazil. In order to do so, the proposed method performance demanded comparison to Brunt classical proposition, as well as to radiometric measurements collected by radiometer balance near the surface observing station.

\section{MATERIAL AND METHODS}

\section{Method theory}

The classical theory concerning the partitioning of radiant energy into different natural processes presupposes that net radiation $(R n)$ reaching a canopy, under sufficient water supply conditions, might be divided into a heat flux consumed in the evaporation process $(\lambda E)$, part in atmospheric air sensible heat $(H)$, ground sensible heat flux $(G)$, and storage energy $(A)$. According to the energy conservation principle (PEREIRA et al., 1997), we have:

$$
\mathrm{Rn}-\mathrm{G}=\lambda \mathrm{E}+\mathrm{H}+\mathrm{A}
$$


After one-day cycle, we can assume that $A$ is negligible, as well as consider that $\lambda E$ and $H$ return from the surface to atmosphere through transpiration and sensible heat (humid air warming). Then, Bowen ratio was determined (BOWEN, 1926), which is defined by:

$$
\beta=\frac{H}{\lambda E}
$$

Thus, substituting (2) into (1) we have:

$$
\mathrm{Rn}-\mathrm{G}=\lambda \mathrm{E}(1+\beta)
$$

Assuming that vegetated surface temperature corresponds to $T$ ' being equal to air temperature ( $\mathrm{Ta}$ ) under standard measurement conditions; given the fact that sensible heat gain due to storage changes relevant to latent heat turbulent fluxes $(\lambda E)$, sensible heat $(H)$, as well as energy storage in biological syntheses are negligible. Therefore, $\lambda E$ and $H$ can be expressed by the following equations:

$$
\begin{aligned}
& \lambda E=\rho \frac{0,622(e s-e a)}{P} \lambda C v \\
& H=\rho C p\left(T a-T^{\prime}\right) C a
\end{aligned}
$$

where,

$$
\begin{aligned}
& \lambda \mathrm{E} \text { - latent heat flux }\left(\mathrm{MJ} \mathrm{m}^{-2} \mathrm{~s}^{-1}\right) \text {; } \\
& \text { (es - ea) - deficit of water vapor saturation pressure }(\mathrm{kPa}) \text {; } \\
& \mathrm{P} \text { - local atmospheric pressure }(\mathrm{kPa}) \text {; } \\
& \rho \text { - atmospheric air density }\left(\mathrm{kg} \mathrm{m}^{-3}\right) \text {; } \\
& \mathrm{Cv} \text { - aerodynamic conductance of water vapor turbulent transport }\left(\mathrm{m} \mathrm{s}^{-1}\right) \text {; } \\
& \left.\lambda \text { - latent heat of vaporization (given as } 2.45 \mathrm{MJ} \mathrm{kg}^{-1}\right) \text {, } \\
& \mathrm{H} \text { - sensible heat flux to atmospheric air }\left(\mathrm{MJ} \mathrm{m}^{-2} \mathrm{~s}^{-1}\right) \text {, and } \\
& \mathrm{Cp} \text { - specific heat of moist air at constant pressure }\left(\mathrm{MJ} \mathrm{kg}{ }^{-1} \mathrm{C}^{-1}\right) \text {, and } \\
& \mathrm{Ca} \text { - aerodynamic conductance of sensible heat turbulent transport }\left(\mathrm{m} \mathrm{s}^{-1}\right) \text {. }
\end{aligned}
$$

Since the proposed model requires the $\omega$ parameter, which was defined by PENMAN (1956) as the adjustment factor for net radiation on water loss process on natural surfaces, for $\omega$ it was assumed that for a water well-supplied leaf, $\lambda E$ and $H$ are also conditioned by the turbulent transport of moist air due to the temperature difference between the atmospheric air and the leaf ( $T a$ - T') and the air saturation pressure deficit (es - ea). By substituting (4) and (5) into (2), the assumption of similarity between the strength of the vegetation cover and the air allows to propose the following relationship to calculate the Bowen ratio $(\beta)$ :

$$
\beta=\frac{H}{\lambda E}=\frac{\rho \mathrm{Cp}\left(\mathrm{Ta}-\mathrm{T}^{\prime}\right) \mathrm{Ca}}{\frac{\rho 0,622(\mathrm{es}-\mathrm{ea}) \lambda \mathrm{Cv}}{\mathrm{P}}}
$$

Assuming $C a=C v$ and considering $\gamma$ as the psychrometric coefficient given by:

$$
\gamma=\frac{\mathrm{Cp} \mathrm{P}}{0,622 \lambda}
$$

And substituting (7) into (6) we have:

$$
\beta=\frac{\gamma\left(\mathrm{Ta}-\mathrm{T}^{\prime}\right)}{(\mathrm{es}-\mathrm{ea})}
$$


Considering the classic psychometric equation defined by:

$$
\text { ea }=\mathrm{es}^{\prime}-\gamma\left(\mathrm{Ta}-\mathrm{T}^{\prime}\right)
$$

where,

ea - partial pressure exerted by water vapor in the atmosphere at average air temperature $(\mathrm{kPa})$, and

es' - water vapor saturation pressure at the wet bulb temperature $(\mathrm{kPa})$.

Substituting (9) into (8) and canceling identical same terms, we have:

$$
\beta=\frac{\gamma\left(\mathrm{Ta}-\mathrm{T}^{\prime}\right)}{\mathrm{es}-\mathrm{es}^{\prime}+\gamma\left(\mathrm{Ta}-\mathrm{T}^{\prime}\right)}=\frac{1}{\frac{(\mathrm{es}-\mathrm{es})}{\gamma\left(\mathrm{Ta}-\mathrm{T}^{\prime}\right)}+1}
$$

The value of $\mathrm{S}$ corresponds to the tangent to the curve of water vapor saturation pressure to the daily average air temperature $\left(\mathrm{kPa}^{\circ} \mathrm{C}^{-1}\right)$, obtained by the following expression:

$$
\mathrm{S}=\frac{\mathrm{es}-\mathrm{es}}{\left(\mathrm{Ta}-\mathrm{T}^{\prime}\right)}
$$

Substituting (11) in (10) we have:

$$
\beta=\frac{1}{\frac{S}{\gamma}+1}=\frac{\gamma}{S+\gamma}
$$

PENMAN (1956) defined an adjustment factor for net radiation $(\omega)$, given by:

$\omega=\frac{S}{S+\gamma}$

With the expression $\frac{\gamma}{S+\gamma}=1-\omega$, which was substituted in (12), a new conception for the $\beta$ parameter is defined by:

$\beta=1-\omega$

Substituting (14) into (3) and considering the latent vaporization heat $\lambda$, corresponding to $2.45 \mathrm{MJ} \mathrm{kg}^{-1}$, we arrive at:

$$
E=\frac{(R n-G)}{\lambda(2-\omega)}
$$

During the evaporation, transpiration and evapotranspiration processes along the whole daytime, the daily average values for air temperature and altitude were considered to define $\omega$. So $\lambda=2,45 \mathrm{MJ} \mathrm{kg}^{-1}$ and substituting it into (15), $E$ is given by:

$$
\mathrm{E}=0,408 \frac{(\mathrm{Rn}-\mathrm{G})}{(2-\omega)}
$$

in which,

E - humid surface evapotranspiration during solar brightness period (mm day ${ }^{-1}$ );

$\mathrm{G}$ - soil sensible heat flux during daytime $\left(\mathrm{MJ} \mathrm{m}^{-2} \mathrm{dia}^{-1}\right)$;

$\mathrm{Rn}$ - radiation balance on the vegetated surface $\left(\mathrm{MJ} \mathrm{m}^{-2} \mathrm{dia}^{-1}\right)$, and

$\omega$ - weighting factor for net radiation. 
Net radiation can be expressed mathematically through the algebraic sum of two partial radiation balances: the short wave balance (SWB) and the long wave balance (LWB). Thus,

where,

$$
\mathrm{SWB}=\mathrm{Qg}(1-\alpha)
$$

Qg - flux density of global solar radiation $\left(\mathrm{MJ} \mathrm{m}^{-2} \mathrm{dia}^{-1}\right)$,

$\alpha$ - grassy surface albedo or reflective power; assuming the average value corresponding to 0.23 (PEREIRA et al., 1997).

$L W B$ is the accounting between the radiation flux of atmospheric origin (thermal radiation, Qatm) and terrestrial emission (thermal radiation, Qs). As Qatm is a fraction of Qs, which varies according to local weather conditions, it can be stated that $L W B$ will always take on negative value at any $t$ instant of a 24-hour cycle. Thus, we have:

$$
\mathrm{LWB}=\text { Qatm }- \text { Qs }
$$

$L W B$ is the effective emission of the surface expressed in $\mathrm{MJ} \mathrm{m}^{-2}$ day ${ }^{-1}$, and represents the total long wave radiation that the Earth surface issued and did not receive back. It is the long wave radiation emitted by the surface minus the counter-irradiated toward the surface that contributes to atmospheric air heating, causing variations at $H$ current regime. It is possible to assert with high approximation that $L W B$ is converted into $H$. Therefore, $L W B \approx H$. So, we can write by approximation that:

$$
\begin{aligned}
& \mathrm{Rn}=\mathrm{SWB}-\mathrm{H} \\
& \mathrm{H}=\mathrm{SWB}-\mathrm{Rn}
\end{aligned}
$$

Substituting the equation (14) into (3), we have:

$$
\begin{aligned}
& \mathrm{Rn}-\mathrm{G}=\lambda \mathrm{E}[1+(1-\omega)] \\
& \lambda \mathrm{E}=\frac{\mathrm{Rn}-\mathrm{G}}{(2-\omega)}
\end{aligned}
$$

Thus, we have:

$$
1-\omega=\frac{H}{\lambda E}=\frac{(S W B-R n)}{\frac{(R n-G)}{(2-\omega)}}
$$

Therefore, as $G$ is negligible in the daily scale, $R n$ can be expressed by:

$$
\mathrm{Rn}=\mathrm{Qg}(1-\alpha) \frac{(2-\omega *)}{(3-2 \omega *)}
$$

As $\omega$ is a weighting factor dependent on moist air temperature and psychrometric coefficient, which can be calculated by VILLA NOVA et al. (2002) for moist bulb temperatures ranging from $0{ }^{\circ} \mathrm{C}$ to $32{ }^{\circ} \mathrm{C}$. This factor is usually determined by average air temperature. But MONTEITH (1965) suggests that this parameter is obtained based on the average between dry and wet bulb temperatures monitored by a psychrometer.

Thus, $\omega^{*}$ is a weighting factor for solar radiation effect on evapotranspiration, which varies according to local altitude, average air temperature, average air relative humidity and psychrometric coefficient, being obtained through the following expression :

$$
\omega *=\frac{\mathrm{S} *}{\mathrm{~S} *+\gamma *}
$$


where,

$\mathrm{S}^{*}$ - slope of the curve of saturated vapor pressure as a function of dry and wet bulb average temperatures (Tsu);

$\gamma^{*}$ - psychrometric coefficient adjusted with psychrometer average temperatures.

The tabular values of Tsu and $S^{*}$ calculated by VILLA NOVA et al. (2002) were used to calculate $\omega^{*}$ as a function of local altitude, average air temperature and average air relative humidity for studied periods and places.

\section{Verification and validation of estimates}

To gauge the estimates, we used meteorological data recorded at the Experimental Station of the State University of Ponta Grossa, Ponta Grossa, PR (at $969 \mathrm{~m}$ altitude, coordinates of 2505' S and 5009’ W). The soil was classified as typical Haplic Dystrophic Cambisol (Inceptisol) of clayey texture, local climate according to Köeppen is Cfb type - humid subtropical climate.

At experimental site where net radiation was monitored, the whole surface area was vegetated with Pensacola grass (Paspalum notatum Flugge) at a uniform height between 8 and $12 \mathrm{~cm}$, maintained by periodic mowing. At the center, an automatic Campbell Scientific, Inc. weather station was installed to monitor local weather elements, in the period between April $1^{\text {st }}, 2008$ and April 30 ${ }^{\text {th }}, 2011$.

Net radiation data were measured using a Kipp \& Zonen balance radiometer in an automatic weather station. The balance radiometer is coupled to a Campbell Scientific, Inc. data acquisition system, CR-1000 model, programmed to take readings at a frequency of 60 seconds, storing averages every 30 minutes. Initially, instantaneous values of $R n\left(\mathrm{~W} \mathrm{~m}^{-2}\right)$ were obtained, which were subsequently integrated over the day and expressed in $\mathrm{MJ} \mathrm{m}^{-2}$ day $^{-1}$. From original data, we tried to eliminate days that had rainfall values greater than $1.0 \mathrm{~mm}$, as well as days on which maintenance was carried out in the experimental area in order to not interfere with measurements made by sensors.

To determine $L W B$ the following equation was used:

$$
\mathrm{LWB}=-\left[4,90310^{-9} \mathrm{~T}_{\mathrm{a}}^{4}(0,34-0,14 \sqrt{\mathrm{ea}})\left(0,1+0,9^{\mathrm{n}} / \mathrm{N}\right]\right.
$$

where,

Ta - average air temperature (K):

ea - partial vapor pressure $(\mathrm{kPa})$, and

$\mathrm{n} / \mathrm{N}$ - insolation ratio.

Thus, $R n$ was estimated by the accounting between $S W B$ and $L W B$.

Net radiation calculated by both methods referred to dry and wet periods for this location. A set of radiometric data, collected during wet season, was considered for proposition of dependency relation between $R n$ values, being calculated and observed. In order to validate this dependency relationship, a number of relevant independent data on dry season were considered for both methods.

\section{Statistical analysis}

$R n$ values obtained through the proposed methodology were correlated with values estimated by the classical method of Brunt, adapted by DOORENBOS \& PRUITT (1975) and also the balance radiometer values through regression studies. A simple linear regression model that exactly reproduces the exact magnitude of observations can produce a linear point distribution, so that the slope is 1 and intercept is 0 . 
Determination coefficient $\left(\mathrm{R}^{2}\right)$ obtained by regression analysis describes the total variance proportion explained by regression model and has been widely used as a correlation index. However, $\mathrm{R}^{2}$ must not be used alone in a performance analysis, as this statistic parameter may often be unrelated to the difference size between standard value and predicted value by estimate models or other standard measurement mechanisms (WILLMOTT \& WICKS, 1980).

The accuracy of $R n$ estimate equations was expressed by $\mathrm{R}^{2}$ (LEGATES \& McCABE, 1999). This accuracy can be observed through ordered pair dispersion consisting of measured and estimated $R n$ values around the straight line of $45^{\circ}$ on type 1:1 graph, which was quantified by the concordance index chart (WILLMOTT et al., 1985). An index c proposed by CAMARGO \& SENTELHAS (1997) was adopted to indicate linear regression model performance, in association with Pearson correlation coefficients (r) and concordance (d), which was obtained by the product of these two latest statistical parameters. To evaluate estimate errors, mean absolute percentage error (MAPE) and smoothed absolute percentage error (SAPE), described by GOODWIN \& LAWTON (1999) were calculated.

\section{RESULTS AND DISCUSSION}

The method reliability verification test [eq.(24)] obtained from a set of independent data collected on grassy surface for the whole year, generated the determination coefficient of 0.8, Willmott index of 0.91 and performance coefficient of 0.83 (Figure 1).

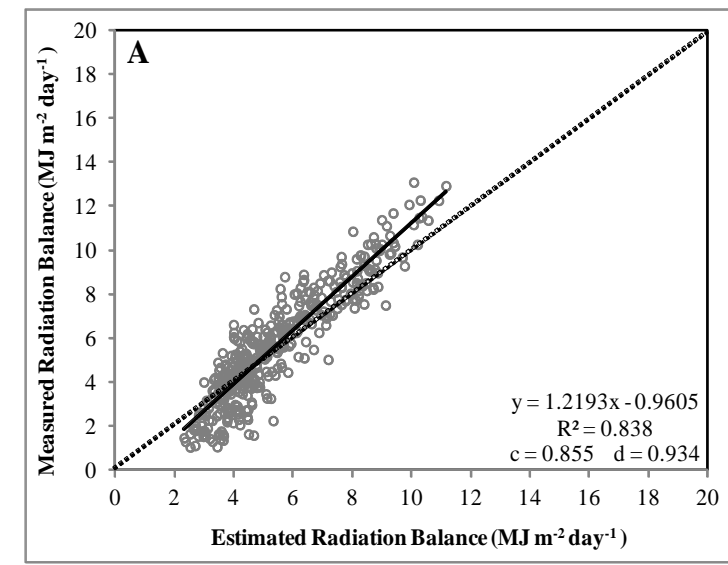

Measured Radiation Balance

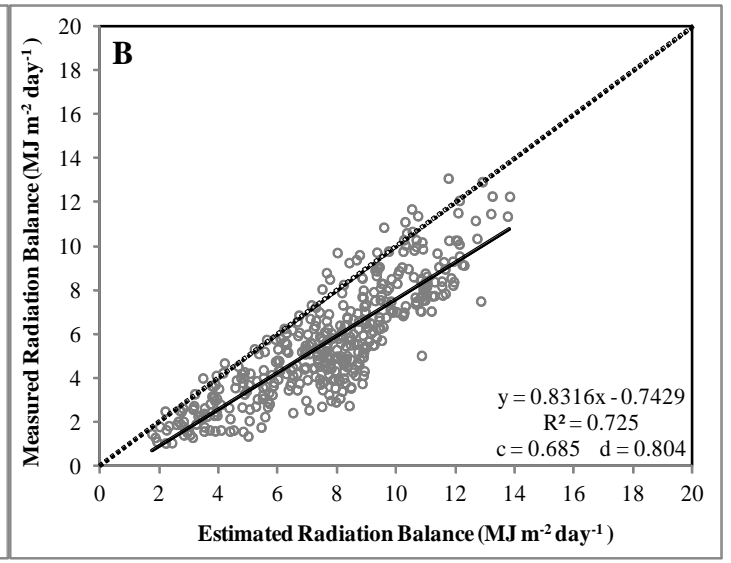

Estimated Radiation Balance

FIGURE 1. Relationship between net radiation measured by net radiometer and estimated by classical methods of Brunt (A) and proposed by ALFARO (2009) (B), considering the set of radiometric data collected throughout the period comprised from April $1^{\text {st }} 2008$ and April 30 2011 in Ponta Grossa, PR, Brazil.

The $\mathrm{R}^{2}$ and $\mathrm{r}$ coefficients provide information about accuracy degree; however, reveal nothing about model effectiveness (PEREIRA et al., 2003; PEREIRA \& VILLA NOVA, 2008). The concordance index (d) equal to 0.91 shows a high accuracy in line with d values found by PEREIRA et al. (2003) and LEGATES \& McCABE (1999). The performance index (c) was 0.83 for location and culture, indicating an excellent performance according to the interpretation criteria described by CAMARGO \& SENTELHAS (1997).

Both accuracy of the simple linear regression model, given by the trendline, and correctness, expressed by data dispersion around $45^{\circ}$ line in 1:1 type graphic were consistent. The $c$ value corresponding to 0.83 exceeded the concordance index considered satisfactory as reported in the literature. According to ROBINSON \& HUBBARD (1990), the lower acceptable limit for the concordance index (d) is 0.75 .

MAPE and SAPE were $38.1 \%$ and $27.4 \%$, respectively, confirming the proposed method feasibility to estimate net radiation on grassy surface at studied location, using equation 24 . 
However, under Piracicaba city in São Paulo State weather conditions, ALFARO (2009) and ALFARO et al. (2013) obtained the following statistical parameters by applying method based on energy balance principle: $\mathrm{R}^{2}=0.90 ; \mathrm{d}=0.93$; $\mathrm{c}=0.88$; MAPE $=8.9 \%$; and SAPE $=9,4 \%$. The same authors obtained $\mathrm{R}^{2}=0.70 ; \mathrm{d}=0.68$; $\mathrm{c}=0.57$; MAPE $=24.3 \%$; and $\mathrm{SAPE}=28.4 \%$ when using the classical Brunt method for Rn estimate.

Probably, higher values of MAPE and SAPE under Ponta Grossa climatic conditions compared to Piracicaba is due to the more pronounced normal water regime from Southern Paraná State in front of shorter drought periods throughout the crop growing seasons. Both normal cyclic climate water balance and sequential prepared for crop years, aiming to validate the proposed method, show that water supply in soil is more satisfactory in Ponta Grossa than in Piracicaba, once water water intakes in first location soil always supersede water exits the second location soil; thus, affecting the incident solar radiation regime on the surface (SMA FOUNDATION ABC, 2013; ADAMUCHIO, 2011; GALVANI, 2008; PEREIRA et al., 2002).

$L W B$ can be estimated by seasonal meteorological measurements through empirical equations, such as Brunt's that considers daily average absolute air temperature, partial water vapor pressure at atmosphere, effective astronomical insolation and photoperiod. The proposed method main advantage, based on energy balance, lies in the fact that this dismisses insolation ratio information, constituting feasible alternative to quantify $R n$ on surface observing stations that do not have equipment for its measurement.

The reliability test of the Brunt classical method obtained from an independent data set collected in grassy surface for the whole year, resulted in a determination coefficient of 0.85 , Willlmott index of 0.95, and a performance coefficient of 0.88 (Figure 1).

Both simple linear regression model accuracy and correctness for the comparative study between net radiation estimated by the classical method and the one observed, were similar to those obtained using the proposed method, differing from studies performed by ALFARO (2009) and ALFARO et al. (2013) in Piracicaba, SP area, during 1996.

MAPE and SAPE for conventional method to estimate grass net radiation of were $27.1 \%$ and $20.7 \%$, respectively; and lower than those obtained by proposed methodology.

Selecting a period of radiometric data regarding the wet season was possible to obtain a linear regression equation that establishes dependence relationship between measured and calculated $R n$ values. That equation generated a determination coefficient of 0.82 , a concordance coefficient of 0.92 , and a performance index of 0.84 when considering the method proposed by ALFARO (2009) to estimate Rn (Figure 2). MAPE and SAPE were respectively correspondent to $32.9 \%$ and $23.0 \%$, demonstrating usability of this method on agrometeorological studies, which aim to plan crop irrigation in the studied region.

Having the same set of experimental data collected during the wet season, a regression study comparing $R n$ estimates obtained by classical method of Brunt and those measured by net radiometer provided a determination coefficient of 0.86 , a concordance coefficient of 0.93 , and a performance index of 0.86 (Figure 2). The amounts of MAPE and SAPE were, respectively, corresponding to $30.7 \%$ and $22.1 \%$.

Proposed method validation, considering the dependence between net radiation balance measured by net radiometer and the one estimated through method developed by ALFARO (2009), was performed considering radiometric data collected during wet season, which were compared with a separate data set, referring to dry season from studied location. Overlooking representativeness and reliability of the proposed model, the same analyses were applied to the Brunt method. 


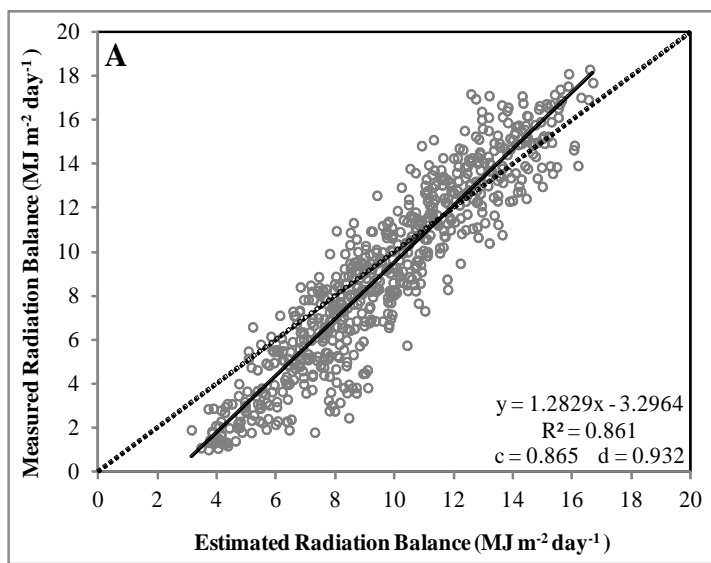

Measured Radiation Balance

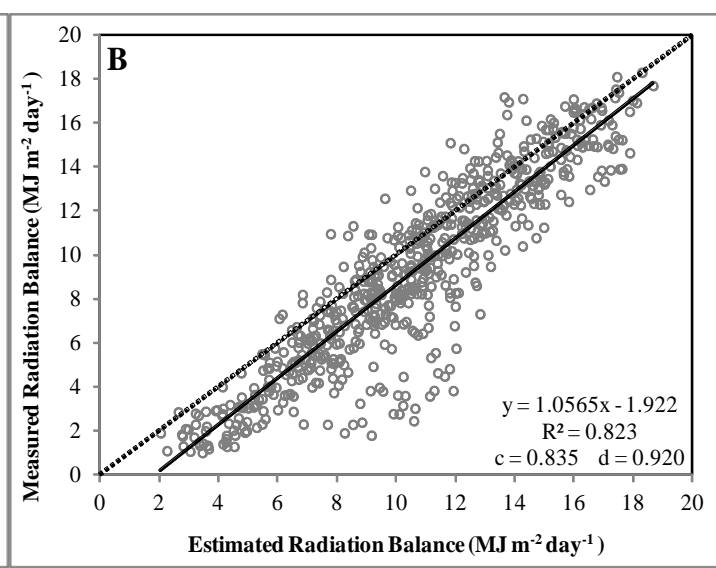

Estimated Radiation Balance

FIGURE 2. Relationship between net radiation measured by the net radiometer and estimated by classical methods of Brunt (A) and proposed by ALFARO (2009) (B), considering the radiometric conditions of the wet season in Ponta Grossa, PR, Brazil.

According to the statistical analyzes performed to validate the adopted methods, it was found that both models accurately estimated $R n$ values for both periods and studied location. These results were statistically confirmed by means of determination coefficients obtained when submitting experimental data to regression analysis. For the $R n$ estimation model, proposed by Brunt, we calculated an $\mathrm{R}^{2}$ of 0.84 , asserting that $84 \%$ of the observed value variations for net radiometer in a ground observation station can be explained through the obtained simple linear regression equation. However, the $R n$ estimation model proposed by ALFARO (2009), which is based on energy balance, showed an $\mathrm{R}^{2}$ equal to 0.73 that is then slightly less accurate when compared to the classical method, for the periods and location under analysis (Figure 3).

The concordance indexes obtained by Brunt method and the one proposed by ALFARO (2009) were 0.83 and 0.91, respectively. Such values, for both methods, revealed high accuracy, since according to WILLMOTT et al. (1985), the closer to 1.0 the $d$ values are, the higher the correlation between proposed model and observed reality. However, index c, used to indicate method performances under study, was 0.76 for the classical and 0.78 for the one proposed by ALFARO (2009). Thus, according to CAMARGO \& SENTELHAS (1997), both methods revealed very good performance (when c value is between 0.76 and 0.85 ).

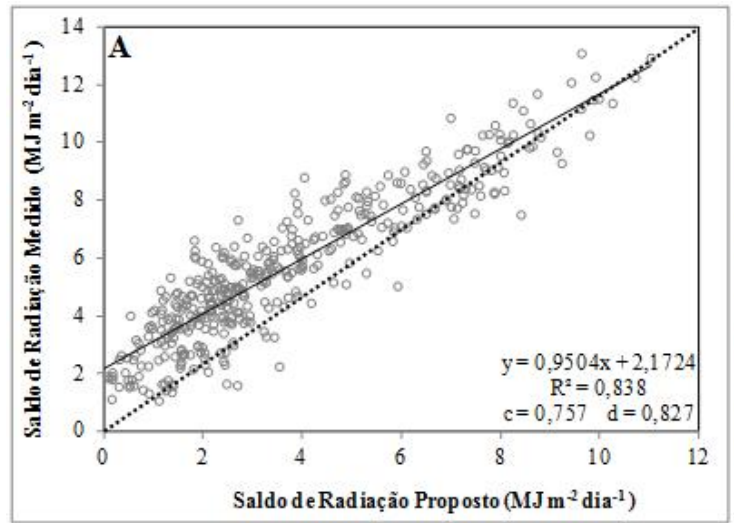

Measured Radiation Balance

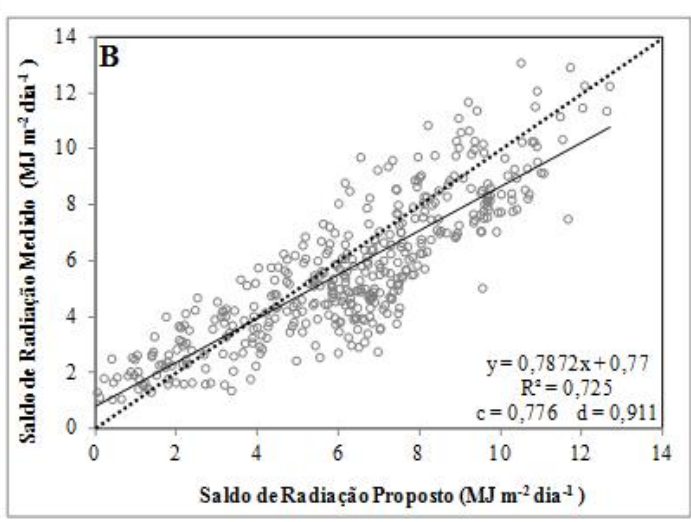

Proposed Radiation Balance

FIGURE 3. Validation of Brunt classical method (A) and the method proposed by ALFARO (2009) (B), considering a set of independent radiometric data collected throughout the dry season in Ponta Grossa, PR, Brazil. 
MAPE and SAPE, when considering the method proposed by Brunt, were $40.6 \%$ and $56.1 \%$, respectively. In contrast to ALFARO (2009) method, values of $28.7 \%$ for MAPE and $27.3 \%$ for SAPE were obtained, which were inferior to those above mentioned.

\section{CONCLUSIONS}

It is possible to estimate the daily net radiation of grass surfaces with good approximation only from global solar radiation, temperature and relative humidity.

The theory based on the energy balance method proposed to estimate the net radiation in grass surface can be recommended to Ponta Grossa city in Paraná State, being reliable when compared to conventional method and has the advantage of not requiring insolation and photoperiod data.

\section{ACKNOWLEDGMENTS}

To the researcher Dr. Antonio Ribeiro da Cunha - FLA/UNESP of Botucatu - for the assistance in meteorological data screening and to CAPES for the financial support during this study completion. To the National Council of Scientific Development - CNPq - for granting financial resources to acquire the complete automatic weather station.

\section{REFERENCES}

ADAMUCHIO, J.G. Respostas de um balanço hídrico devido às periodicidades e equações de estimativa do armazenamento da água no solo. 2011. 253 f. Dissertação (Mestrado Ciência do Solo) - Universidade Federal do Paraná, Curitiba, 2011.

ALFARO, A.T.S. Modelo de estimativa da radiação líquida e sua aplicação na determinação da evapotranspiração potencial. 2009. 78 f. Dissertação (Mestrado em Agronomia) - Universidade Estadual de Ponta Grossa, Ponta Grossa, 2009.

ALFARO, A.T.; NOVA, N.A.V.; PEREIRA, A.B.; BERUSKI, G.C. Modelo baseado no método do balanço de energia para estimar a radiação líquida em superfície gramada. Scientia Rural, Ponta Grossa, v.8, p.1-14, 2013.

ALLEN, R.G.; PEREIRA, L.S.; RAES, D.; SMITH, M. Crop evapotranspiration. Guidelines for computing crop water requirements. Rome: FAO, 1998. 300 p. (FAO - Irrigation and Drainage Paper, 56).

BOWEN, I.S. The ratio of heat losses by conductions and by evaporation from any water surface. Physical Review, Nova York v.27, p.779-87, 1926.

CAMARGO, A.P.; SENTELHAS, P.C. Avaliação do desempenho de diferentes métodos de estimativa da evapotranspiração potencial no Estado de São Paulo, Brasil. Revista Brasileira de Agrometeorologia, v.5, n.1, p.89-97, 1997.

DOORENBOS, J.; PRUITT, W.O. Guidelines for predicting crop water requirements. Santa Maria, Rome, 1975. 179 p. (FAO Irrigation and Drainage Paper, 24).

FRITSCHEN, L.J.; FRITSCHEN, C.L. Calibration of shielded net radiometers. Agronomy Journal, Madison, v.99, n.1, p. 297-303, 2007.

GALVANI, E. Estudo comparativo dos elementos do Balanço Hídrico Climatológico para duas cidades do Estado de São Paulo e para Paris. Confins [Online], v.4, n.4, 2008. Disponível em: < http://confins.revues.org/4733> DOI: 10.400/confins.4733

GOODWIN, P.; LAWTON, R. On the asymmetry of the symmetric MAPE. International Journal of Forecasting, Oxford, v.15, n.2, p.405-408, 1999.

HELDWEIN, A.B.; MALDANER, I.C.; RADONS, S.Z.; LOOSE, L.H.; LUCAS, D.D.P.; HINNAH, F.D. Estimativa do saldo de radiação em girassol como função da radiação solar global. 
Revista Brasileira de Engenharia Agrícola e Ambiental, Campina Grande, v.16, n.2, p.194-199, 2012.

LEGATES, D.R.; McCABE JR, G.F. Evaluating the use of "goodness-of-fit" measures in hydraulic and hydroclimatic model validation. Water Resources Research, Amsterdam, v.35, n.1, p.233-241, 1999.

LIMA, E.P.; SEDIYAMA, G.C.; SILVA, B.B.; GLERIANI, J.M.; SOARES, V.P. Seasonality of net radiation in two sub-basins of Paracatu by the use of MODIS sensor products. Engenharia Agrícola, Jaboticabal, v.32, n.6, p.1184-1196, 2012.

MONTEITH, J.L. Evaporation and environment: Rothamsted Experimental Station. Harpenden, Herts, v.19, n.3, p.205-34, 1965.

PENMAN, H.I. Evaporation: an introductory survey. Journal of Agricultural Science, Toronto, v.4, n.1, p.9-29, 1956.

PEREIRA, A.B.; NOVA, N.A.V.; ALFARO, A.T. Necessidades hídricas de citros e macieiras a partir da área foliar e da energia solar. Revista Brasileira de Fruticultura, Jaboticabal, v.31, p.671679, 2009.

PEREIRA, A.B.; NOVA, N.A.V.; PIRES, L.F.; ALFARO, A.T. Transpiration of irrigated apple trees and citrus from a water potential gradient approach in the leaf-atmosphere system. Revista Brasileira de Meteorologia, São José dos Campos, v.26, p.181-188, 2011.

PEREIRA, A.B.; VILLA NOVA, N.A. Parâmetros fisiológicos e produtividade da batateira (Solanum tuberosum L.) submetida a três níveis de irrigação. Engenharia Agrícola, Jaboticabal, v.22, n.1, p.127-134, 2002.

PEREIRA, A.B.; VILLA NOVA, N.A. Potato maximum yield as affected by crop parameters and climatic factors in Brazil. HortScience, North Carolina, v.43, n.5, p.1611-1614, 2008.

PEREIRA, A.B.; VILLA NOVA, N.A.; GALVANI, E. Estimation of global solar radiation flux density in Brazil as a function of a single measurement at solar noon. Biosystems Engineering, Edinburg, v.86, n.1, p.27-34, 2003.

PEREIRA, A.R.; ANGELOCCI, L.R.; SENTELHAS, P.C. Agrometeorologia: fundamentos e aplicações práticas. Guaíba: Agropecuária, 2002. 478 p.

PEREIRA, A.R.; VILLA NOVA, N.A.; SEDIYAMA, G.C. Evapo(transpiração). Piracicaba: FEALQ, 1997. 183 p.

PEREIRA, L. de C. Caracterização do balanço de energia no Vale do Curaçá - Bahia. 2006. 80 f. Dissertação (Mestrado em Agronomia) - Universidade Federal da Bahia, Salvador, 2006.

ROBINSON, J.M.; HUBBARD, K.G. Soil water assessment model for several crops in high plains. Agronomy Journal, Madison, v.82, n.4, p.1141-1148, 1990.

RYU, Y.; KANG, S.; MOON, S.; KIM, J. Evaluation of land surface radiation balance derived from moderate resolution imaging spectroradiometer (MODIS) over complex terrain and heterogeneous landscape on clear sky days. Agricultural and Forest Meteorology, Amsterdam, v.48, n.4, p.15381552, 2008.

SENTELHAS, P.C.; NASCIMENTO, A.L.C. Variação sazonal entre o saldo de radiação e a irradiância solar global. Revista Brasileira de Meteorologia, São José dos Campos, v.18, n.1, p.7177, 2003.

SMA - Sistema de Monitoramento Agrometeorológico. Fundação. Pesquisa e Desenvolvimento Agropecuário, Santo André. Disponível em: <http://sma.fundacaoabc.org.br> Acesso em: 5 jul. 2013. 
TODD, R.W.; EVETT, S.R.; HOWELL, T.A. The Bowen ratio-energy balance method for estimating latent heat flux of irrigated alfalfa evaluated in a semi-arid, advective environment. Agricultural and Forest Meteorology, Amsterdam, v.103, n.1, p.335-348, 2000.

VILLA NOVA, N.A.; MIRANDA, J.H.; PEREIRA, A.B.; SILVA, K.O. Estimation of the potential evapotranspiration by a simplified Penman method. Engenharia Agrícola, Jaboticabal, v.26, n.3, p.713-721, 2006.

VILLA NOVA, N.A.; PEREIRA, A.B. Ajuste do método de Priestley-Taylor às condições climáticas locais. Engenharia Agrícola, Jaboticabal, v.26, n.2, p.395-405, 2006.

VILLA NOVA, N.A.; PEREIRA, A.B.; PEREIRA, A.R. Ajustes de S e W da equação de Penman em função da média entre as temperaturas seca e úmida do ar. Irriga, Botucatu, v.7, n.3, p.241-253, 2002.

VILLANUEVA, J.G. Estudo do coeficiente de transparência do vapor d'água sobre a cultura do feijão. 1987. 58 f. Dissertação (Mestrado em Agrometeorologia) - Escola Superior de Agricultura "Luiz de Queiroz", Universidade de São Paulo, Piracicaba, 1987.

WILLMOTT, C.J.; ACKLESON, S.G.; DAVIES, R.E.; FEDDEMA, J.J.; KLINK, K.M.; LEGATES, D.R.; O’DONNELL, J.; ROWE, C.M. Statistics for the evaluation and comparison of models. Journal of Geophysical Research, Washington, v.90, n.5, p.8995-9005, 1985.

WILLMOTT, C.J.; WICKS, D.E. An empirical method for the spatial interpolation of monthly precipitation within California. Physical Geography, Columbia, v.1, n.1, p.59-73, 1980. 


\section{ERRATA}

Doi: http://dx.doi.org/10.1590/1809-4430-Eng.Agríc.v35n3errata1/2015

No artigo "VALIDATION STUDY OF AN OVERALL RADIATION BALANCE ESTIMATION METHOD UNDER PONTA GROSSA (PR) BRAZIL WEATHER CONDITIONS" publicado na revista Engenharia Agrícola, no volume 34, número 3: páginas 461-472, na página 470, onde se lia:

\section{ACKNOWLEDGMENTS}

To the researcher Dr. Antonio Ribeiro da Cunha - FLA/UNESP of Botucatu for the assistance in meteorological data screening and to CAPES for the financial support during this study completion. To the National Council of Scientific Development - $\mathrm{CNPq}$ - for granting financial resources to acquire the complete automatic weather station.

Leia-se:

\section{ACKNOWLEDGMENTS}

To the researcher Dr. Antonio Ribeiro da Cunha - FLA/UNESP of Botucatu - for the assistance in meteorological data screening and to CAPES for the financial support during this study completion. To the National Council of Scientific Development $\mathrm{CNPq}$ - for granting financial resources to acquire the complete automatic weather station. Special thanks are also devoted to the Fundação Araucária - FA - for the Productivity Fellowship in Research granted to the second author of the current manuscript. 